\title{
FEASIBILITY ANALYSIS OF FRESHWATER FISH FARMING BUSINESS DEVELOPMENT IN PRINGSEWU DISTRICT
}

\author{
Muhiddin Sirat $^{1}$. Shofyan Shaleh ${ }^{2}$. Ratna Ermawati ${ }^{2}$. \\ Muhammad Mirandy Pratama Sirat ${ }^{2}$. Deny Sapto Chondro \\ Utomo $^{3}$
}

Ringkasan This research had wo aims, the first was to see and analyze the business offreshwater fish farming in Pringsewu District which is feasible or not to be developed. The second aim was to find out whether the freshwater fish farming business in Pringsewu District remain feasible to be developed if there was a decrease in production levels and an increased in production costs. This research analyzed several aspects of business feasibility, namely marketing aspect, production aspect, management aspect dan financial aspect. In the financial aspect, two approaches were used, that were analysis of unpaid business feasibility using the Benefit Cost Ratio (B/C Ratio), Break event point (BEP), Return On Invesment (ROI) analysis tools and discounted business feasibility analysis with the Net Present Value (NPV), Net Benefit Cost Ratio $($ Net $B / C)$, Internal rate of retur (IRR), Gross Benefit Cost Ratio (Gross B/C),

\footnotetext{
${ }^{1}$ Jurusan Ekonomi Pembangunan, Fakultas Ekonomi dan Bisnis, Universitas Lampung) ${ }^{2}$ )Jurusan Peternakan, Fakultas Pertanian, Universitas Lampung. ${ }^{3}$ ) 3Jurusan Perikanan dan Kelautan, Fakultas Pertanian, Universitas Lampung. Jl. Soemantri Brodjonegoro No. 1 Gedong Meneng, Rajabasa, Bandar Lampung 35145 Indonesia

E-mail: rendy_sirat@yahoo.com
}

Payback period analysis tools. The results of this study indicated that the aspects of marketing, production aspect, and management aspect have the potential to be developed, as well as the financial aspects with the feasibility analysis of non-discounted shows that the business of freshwater fish farming in Pringsewu District is feasible to be developed. The results of the sensitivity analysis also show that the business is still feasible to be developed despite a decline in production levels and an increased in production costs.

Keywords Business Development, Business Feasibility, Project Evaluation, Freshwater Fish Farming

Received : 15 Nopember 2019

Accepted : 14 Januari 2020

\section{PENDAHULUAN}

Sektor perikanan merupakan salah satu sektor yang menjadi penggerak perekonomian di Indonesia. Menurut data Statistik Indonesia dari Statistik (2019), jumlah produksi perikanan budidaya di Indonesia mencapai angka 16.114.991 
ton yang di dalamnya meliputi budidaya jaring apung, jaring tancap, karamba, kolam, minapadi sawah, rumput laut, tambak dan budidaya laut lainnya. Jumlah tersebut jauh lebih besar dibandingkan jumlah produksi perikanan tangkap yaitu sebesar 7.071.453 ton yang terdiri dari perikanan tangkap di laut dan perairan umum daratan. Hal ini menunjukan bahwa perikanan budidaya memiliki potensi yang besar untuk dapat dikembangkan dalam menunjang kebutuhan protein hewani terutama dari ikan untuk konsumsi masyarakat Indonesia.

Salah satu daerah yang memiliki potensi dalam pengembangan perikanan budidaya di Indonesia adalah Provinsi Lampung. Menurut data Statistik (2019) bahwa jumlah produksi budidaya perikanan Provinsi Lampung pada tahun 2017 berada pada urutan keempat terbesar di Pulau Sumatera yaitu dibawah Provinsi Sumatera Selatan (538.282 ton), Provinsi Sumatera Barat (266.991 ton) dan Provinsi Sumatera Utara (185.012 ton). Produksi budidaya perikanan tersebut memberikan sumbangan terhadap Produk Domestik Regional Bruto (PDRB) Provinsi Lampung sebesar 13.356.170,96 (dalam juta rupiah) dengan distribusi terhadap PDRB sebesar 5,62\%. Menurut data dari Kelautan Perikanan Dalam Angka tahun 2018 dan seiring data Lampung (2019) bahwa Kabupaten Pringsewu berkontribusi cukup besar pada jumlah produksi budidaya perikanan air tawar di Provinsi Lampung pada tahun 2017 yaitu pada urutan keempat (6.202,32 ton) setelah Lampung Tengah (35.341,00 ton), Lampung Selatan (12.224,34 ton) dan Lampung Timur (7.370,17 ton) dari total di Provinsi Lampung sebesar 81.676,95 ton.
Kontribusi perikanan budidaya di kolam air tawar ini lebih besar dibandingkan perikanan budidaya di subsektor kolam air deras (689,10 ton), karamba $(659,46$ ton) dan jaring apung tawar (478,20 ton). Kabupaten Pringsewu tidak memiliki subsektor budidaya laut dikarenakan dari kondisi geografis Kabupaten Pringsewu berada jauh dari perairan air laut. Kabupaten Pringsewu terkenal sebagai salah satu penghasil perikanan air tawar terbesar di Provinsi Lampung.

Berdasarkan data dari Pringsewu (2017) bahwa sentra perikanan air tawar di Kabupaten Pringsewu berada di Kecamatan Pagelaran dengan jumlah produksi ikan air tawar terbesar dibandingkan kecamatan lainnya yaitu 4.770,03 ton dengan rincian produksi yaitu komoditi ikan mas sebesar 2.333,23 ton, komoditi ikan lele sebesar 1.659,08 ton, komoditi ikan gurame sebesar 245,88 ton, komoditi ikan nila sebesar 301,81 ton, dan komoditi ikan patin sebesar 230,03 ton. Pada tahun 2017 luas potensi perikanan budidaya ikan air tawar seluas 1.067,10 $\mathrm{Ha}$, dengan luas lahan yang sudah dimanfaatkan sebesar 516,60 Ha. Peluang usaha budidaya kolam di Kabupaten Pringsewu sebesar 550,5 Ha atau $51 \%$ pemanfaatan yang belum dilakukan sepenuhnya. Hal ini seharusnya dapat menjadi peluang prospektif dan pilihan utama untuk dikembangkan agar dapat meningkatkan nilai tambah dan pendapatan masyarakat Kabupaten Pringsewu. Tujuan penelitian ini yaitu mengetahui dan menganalisis apakah usaha budidaya ikan air tawar di Kabupaten Pringsewu berdasarkan aspek non finansial dan aspek finansial layak untuk dikembangkan, serta untuk mengetahui apakah usaha budidaya ikan air tawar di Kabupa- 


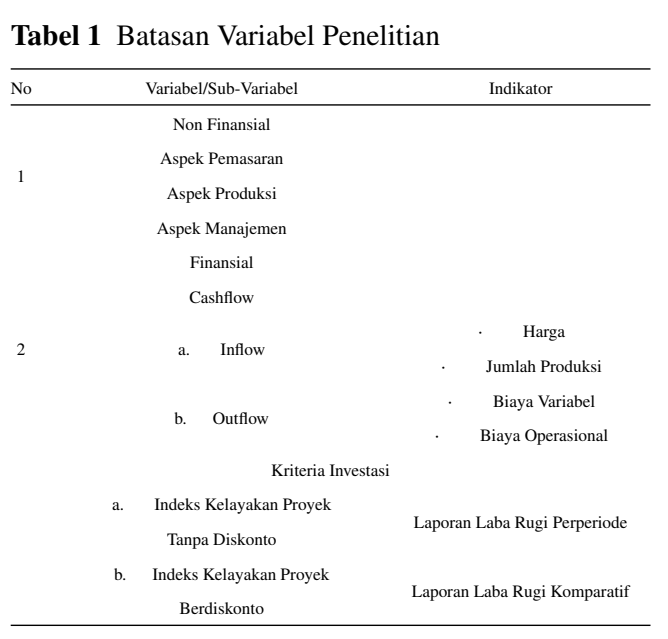

ten Pringsewu tetap layak dikembangkan jika terjadi penurunan tingkat produksi dan peningkatan biaya produksi. Berdasarkan uraian di atas maka penulis melakukan analisis kelayakan pengembangan usaha budidaya ikan air tawar di Kabupaten Pringsewu.

\section{MATERI DAN METODE}

Penelitian ini dilakukan pada FebruariSeptember 2019 di Desa Pagelaran Kecamatan Pagelaran Kabupaten Pringsewu. Variabel dalam penelitian usaha budidaya ikan air tawar ini meliputi aspek non-finansial dan aspek finansial yang disajikan pada Tabel 1 .

Penelitian ini bersifat deskriptif kuantitatif sehingga jenis data yang dibutuhkan untuk mendukung penelitian ini adalah data kuantitatif dan data kualitatif. Data yang digunakan dalam penelitian ini adalah data primer yang diperoleh dari hasil kuesioner dan wawancara, serta data sekunder yang berasal dari data yang bersumber dari Badan Pusat Statistik dan dinas terkait.

Teknik pengumpulan data dalam penelitian ini berasal dari studi pustaka dan
Tabel 2 Tiga Desa Produksi Ikan Mas Terbesar di Kecamatan Pagelaran pada tahun 2017

\begin{tabular}{ccc}
\hline No & Desa & Jumlah Produksi (Ton) \\
\hline 1 & Pagelaran & 262.5 \\
2 & Panutan & 205.75 \\
3 & Lugusari & 165 \\
\hline
\end{tabular}

studi lapangan dengan metode survei. Pada penelitian ini digunakan dua tahap pengambilan sampel yaitu penentuan sampel lokasi dan sampel perusahaan. Penentuan sampel lokasi menggunakan metode Purposive sampling. Lokasi di Kabupaten Pringsewu yang diambil sampelnya disajikan pada Tabel 2. Penentuan sampel perusahaan menggunakan Proportionate stratified random sampling atau teknik pengambilan sampel berdasarkan strata (Sugiyono, 2008). Penelitian ini bersifat deskriptif kuantitatif sehingga peneliti menentukan jumlah sampel sebanyak $15 \%$ dari populasi sebesar 30 petani budidaya ikan dengan perhitungan $15 \%$ x $30=4.50$. Berdasarkan perhitungan jumlah sampel yang ditentukan diperoleh hasil sebesar 4.50 yang kemudian dibulatkan menjadi 4 sehingga sampel yang digunakan sebanyak 4 petani budidaya ikan mas.

Analisis kelayakan usaha tanpa diskonto digunakan untuk menganalisis usaha secara finansial dalam jangka pendek sehingga pada analisis ini tidak terlalu mementingkan nilai uang yang berubah dalam proses analisisnya. Analisis ini menggunakan 3 perhitungan investasi yaitu :

\section{Benefit Cost Ratio}

(B/C Ratio) Adalah ukuran perbandingan antara pendapatan (Benefit $=B$ ) dengan total biaya produksi $($ Cost $=\mathrm{C})$. Dalam batasan besaran nilai B/C dapat diketahui apakah suatu usaha menguntungkan atau tidak. Kriteria rasio manfaatbiaya Benefit Cost Ratio (BCR) untuk 
menganalisis investasi usaha yang memiliki umur ekonomis $\mathrm{t}(\mathrm{t}=1,2,3$, ...., n) tahun dilakukan berdasarkan formula (Gaspersz, 2002).

${ }_{B}^{B} /$ Ratio $=\frac{P W \text { Benefit }}{P W \text { Cost }}=\left\{\sum P F_{t}\left(B_{t}\right)\right\} /\left\{\sum P F_{t}\left(C_{t}\right)\right\}$

dimana; PW benefit: Present Worth Benefit ( Kemanfaatan yang dinai sekarang/pasar); PW Cost: Present Worth Cost (biaya yang dinilai dengan harga sekarang).

Berdasarkan persamaan tersebut, Suatu proyek dikatakan memiliki keuntungan ekonomis, layak dilaksanakan, apabila mempunyai nilai $\mathrm{B} / \mathrm{C}$ ratio (i) lebih besar daripada satu, (B/C ratio(i) $>1)$. Jika nilai $\mathrm{B} / \mathrm{C}$ ratio (i) lebih kecil daripada satu $(\mathrm{B} / \mathrm{C}$ ratio(i) $<1)$ maka proyek industri akan mendatangkan kerugian ekonomis apabila dilaksanakan.

\section{Break Event Point (BEP)}

BEP adalah suatu analisis untuk menentukan dan mencari jumlah barang atau jumlah jasa yang harus dijual kepada konsumen pada tingkat harga tertentu untuk menutupi biaya-biaya yang timbul serta mendapatkan keuntungan, dihitung dengan persamaan Bambang (2001).

$B E P=\frac{F C}{P-V C}$

dimana; FC: Biaya tetap yang nilainya cenderung stabil tanpa dipengaruhi unit yang diproduksi; P: Harga jual per unit; VC:Biaya variabel yang besar nilainya tergantung pada banyak sedikitnya jumlah barang yang diproduksi.

\section{Return On Invesment (ROI)}

Pengukuran ROI menurut Hanafi (2010) adalah penilaian kemampuan perusahaan untuk menghasilkan laba bersih berdasarkan tingkat aset yang dimiliki perusahaan dan investor. ROI mempunyai kelebihan dalam menilai kemampuan perusahaan untuk membandingkan laba setelah pajak dengan aktiva perusahaan sehingga nantinya dapat diketahui ROI perusahaan (Harjito and Martono, 2005) sedangkan menurut Syamsuddin (2007) menyatakan bahwa semakin tinggi ROI maka semakin baik keadaan suatu perusahaan.

$R O I=\frac{N P A T}{T A}$

dimana; NPAT: Pendapatan bersih setelah pajak; TA: jumlah asset yang dimiliki perusahaan dan investor.

Analisis Kelayakan Usaha Berdiskonto pada umumnya dilakukan untuk suatu usaha yang berjangka waktu lama atau panjang. Analisis ini memasukkan pengaruh faktor waktu dalam nilai uang.

\section{Net Present Value (NPV)}

suatu proyek feasible atau tidak. Net Present Value yaitu selisih antara Present Value dari investasi dengan nilai sekarang dari penerimaan-penerimaan kas bersih (aliran kas operasional maupun aliran kas terminal) di masa yang akan datang (Ibrahim, 2003), jika NPV $>0$ maka usaha layak untuk dilakukan, ika NPV $<0$ maka usaha tidak layak untuk dilakukan

$N P V=\sum_{i=1}^{n} \frac{N B}{(1+i) n}$

dimana; NB: benefit - cost; i: Discount factor; n: waktu/umur ekonomi

Net Benefit Cost Ratio (Net B/C)

Net benefit cost ratio merupakan perbandingan antara net benefit yang telah 
di discount positif $(+)$ dengan net benefit yang di diskon (-). Jika nilai Net $\mathrm{B} / \mathrm{C}>1$ berarti gagasan usaha/proyek tersebut layak untuk dikerjakan, jika Net $\mathrm{B} / \mathrm{C}<1$ maka usaha atau proyek tersebut tidak layak untuk dijalankan. Nilai NET B/C =1 menunjukkan cash in flow sama dengan cash out flow.

$N e{ }^{B} / C=\frac{\sum N P V(+)}{\sum N P V(-)}$

\section{Internal Rate of Return (IRR)}

Internal Rate of Return adalah suatu tingkat discount rate yang menghasilkan net present value sama dengan nol, dengan rumus Ibrahim (2003), jika IRR $>$ Tingkat bunga maka usaha layak untuk dijalankan, jika IRR < Tingkat bunga maka usaha tidak layak untuk dijalankan.

$I R R=i_{1}+\frac{N P V_{1}}{N P V_{1}-N P V_{2}}\left(i_{2}-i_{1}\right)$

dimana; i1 : Tingkat bunga terendah yang memberikan nilai NPV positif; i2 : Tingkat bunga terendah yang memberikan nilai NPV negatif ; NPV1 : Nilai pada tingkat bunga terendah dengan NPV positif; NPV2 : Nilai pada tingkat bunga terendah dengan NPV negatif.

\section{Gross Benefit Cost Ratio (Gross B/C)}

Menurut Ibrahim (2003) Gross B/C adalah perbandingan antara benefit kotor yang telah di discount dengan cost secara keseluruhan yang telah di discount, Jika Gross B/C > 1, maka usaha layak (feasible) untuk dijalankan.

$\operatorname{Gross}^{B} / C=\frac{\sum B(1+r)^{n}}{\sum C(1+r)^{n}}$

Payback Periode (PP)
Jika PP < Lama investasi maka usaha layak dilakukan, jika PP > Lama investasi maka usaha tidak layak dilakukan (Ibrahim, 2003)

$P P=T p^{-1}+\frac{\text { Sisa hutang }}{\text { Net Benefit Setelah Hutang }}(8)$

dimana; $\mathrm{TP}^{-1}$ adalah tahun sebelum terdapat PP

Analisis sensivitas merupakan analisis yang dilakukan untuk mengetahui akibat dari perubahan parameter-parameter produksi terhadap perubahan kinerja sistem produksi dalam menghasilkan keuntungan.

\section{HASIL DAN PEMBAHASAN}

Seluruh hasil panen (Tabel 3) pembudidaya selalu terjual dengan harga yang relatif stabil sehingga dapat dikatakan bahwa usaha ini memiliki pasar yang pasti. Berdasarkan hasil penelitian, permintaan akan ikan mas selalu mengalami peningkatan sehingga para petani kurang mampu memenuhi permintaan pasar yang tinggi. Hal ini mengindikasikan bahwa dari segi pemasaran usaha budidaya ikan air tawar ini layak untuk dikembangkan. Penelitian yang dilakukan oleh Sudana et al. (2013) menyebutkan bahwa aspek pemasaran memberikan kontribusi terbesar peningkatan pendapatan petani karena walaupun aspek pemasaran sudah berjalan cukup baik, namun kontinuitas produksi yang belum optimal dapat mempengaruhi pendapatan petani.

Analisis aspek produksi mengacu pada target penjualan yang akan dicapai oleh suatu perusahaan. Faktor-faktor pada analisis aspek produksi yaitu sebagai berikut : 
Tabel 3 Penjualan Ikan Mas Perusahaan Sampel Selama 1 Musim Panen

\begin{tabular}{ccccc}
\hline \multirow{2}{*}{ Nama Pemilik } & Luas Kolam & Produksi & Harga & Penjualan \\
\cline { 2 - 5 } & $\left(\mathrm{M}^{2}\right)$ & $(\mathrm{Kg})$ & (Rupiah) & $($ Rupiah) \\
\hline Jawari & 8.000 & 3.600 & 23.500 & 84.600 .000 \\
Edi & 5.000 & 2.250 & 23.500 & 52.875 .000 \\
Pudi & 2.300 & 900 & 23.500 & 21.150 .000 \\
Witanto & 1.800 & 720 & 23.500 & 16.920 .000 \\
\hline Jumlah & & 7.470 & & 175.545 .000 \\
Rata-rata & & 1.868 & & 43.886 .250 \\
\hline
\end{tabular}

\section{a. Lokasi Usaha}

Desa Pagelaran Kecamatan Pagelaran Kabupaten Pringsewu, sangat mendukung untuk lokasi usaha budidaya ikan air tawar. Lokasi desa permukaan tanahnya adalah dataran rendah, lokasi yang dekat dengan pasar induk dan rumah makan juga menjadi salah satu faktor pendukung, sehingga dalam proses pemasaran tidak terlalu jauh dan dapat mengurangi biaya transportasi bila ingin melakukan pemasaran langsung ke konsumen.

\section{b. Kapasitas Produksi}

Berdasarkan hasil observasi, rata-rata kolam produksi yang digunakan dalam usaha usaha budidaya ikan air tawar ini berbentuk persegi panjang dengan kapasitas tebaran per kolamnya yang berbedabeda sesuai ukuran luas masing-masing kolam. Tetapi berdasarkan keterangan dari responden pada penelitian ini yaitu maksimal penebaran benih ikan yang digunakan untuk pembesaran biasanya sejumlah $100 \mathrm{Kg} / 1000 \mathrm{~m}^{2}$, hal tersebut dilakukan supaya benih ikan tidak stress dan mudah mati, selain itu juga untuk memudahkan dalam perhitungan pemberian pakan nya. Dengan tebaran diangka tersebut mereka percaya tingkat SR nya (Survival Rate) ratarata diangka 60 sampai 90 persen.

Dari hasil penelitian, diperoleh asumsi tingkat pertumbuhan produksi sebesar 9 persen setiap 3 bulan (Tabel 4).
Tabel 4 Asumsi Pertumbuhan Tingkat Produksi Perusahaan Sampel

\begin{tabular}{ccc}
\hline No. & Nama Pemilik & Tingkat Pertumbuhan produksi (\%) \\
\hline 1 & Jawari & 10 \\
2 & Edi & 8 \\
3 & Pudi & 10 \\
4 & Witanto & 8 \\
& Jumlah & 36 \\
\hline
\end{tabular}

Asumsi tingkat pertumbuhan tersebut diperoleh dari rata-rata tingkat pertumbuhan produksi perusahaan sampel, dimana besaran peningkatannya disesuaikan dengan kapasitas produksi setiap perusahaan sampel. Tingkat pertumbuhan ini yang nantinya digunakan sebagai metode peramalan produksi pada periode panen berikutnya.

\section{c. Ketersediaan Bahan Baku}

Dalam pengadaan benih ikan untuk pembesaran, pembudidaya - pembudidaya yang berada di Desa Pagelaran tidak mengalami kendala dikarenakan di lokasi tersebut terdapat beberapa pembudidaya yang memproduksi benih ikan untuk pembesaran sehingga tidak terlalu sulit dalam memperoleh benih. Jarak yang tidak terlalu jauh dengan pembudidaya yang memproduksi benih ikan untuk pembesaran menjadi salah satu keuntungan dipilihnya Desa Pagelaran ini sebagai lokasi usaha budidaya ikan air tawar. Semua responden pada penelitian ini mengambil benih ke pembudidaya pembenihan dengan harga benih tersebut berada diangka Rp.125 per ekor. 
Selain pengadaan benih, pengadaan input produksi lain seperti pakan, pupuk dan obat di Desa Pagelaran ini juga bisa terbilang mudah, karena di lokasi tersebut terdapat beberapa toko atau reseller yang menjual input produksi tersebut. Beberapa pembudidaya juga ada yang bermitra sebagai pelanggan tetap dengan toko penyedia input produksi tersebut sehingga tidak terlalu sulit untuk mendapatkan input produksi yang dibutuhkan. Cara pembeliannya pun mudah yaitu dengan memesan langsung dari resseler atau agen yang berada di sekitar lokasi budidaya yaitu di Desa Pagelaran.

Pada tahap pengadaan sarana produksi, para pembudidaya ikan air tawar ini juga tidak dikenakan biaya transportasi karena pada tahap ini biaya transportasi sarana produksi seperti benih ditanggung oleh penjual, hal tersebut dikarenakan jarak yang tidak telalu jauh dengan tempat produksi benih dan toko penyedia input produksi seperti pakan, obat dan pupuk.

\section{d. Ketersediaan Sumber Daya Manusia}

Dalam memenuhi kebutuhan tenaga kerja pada usaha budidaya ikan air tawar di Desa Pagelaran Kecamatan Pagelaran Kabupaten Pringsewu tidak terlalu sulit untuk dicari. Berdasarkan hasil wawancara dengan beberapa pemilik budidaya ikan, karyawan budidaya ratarata berasal dari daerah sekitaran Desa Pagelaran Kecamatan Pagelaran. Bagi pemilik budidaya dalam bidang pembesaran ikan ini, biasanya mereka tidak perlu menggunakan tenaga kerja ahli atau biasa disebut teknisi. Dikarenakan pembudidaya dengan karyawan yang dipekerjakan sudah memahami proses produksi serta ancaman - ancaman yang biasa dihadapi dalam mem- budidayakan ikan air tawar sehingga resikonya tidak cukup besar, mulai dari tingkat panen yang cukup sampai biaya produksi yang tidak terlalu tinggi.

Tenaga kerja di Desa Pagelaran ini juga terbilang mudah untuk dicari dan memiliki keahlian di bidang ini, karena rata-rata para masyarakat di daerah ini sudah berpengalaman dalam bidang ini. Dari seluruh perusahaan sampel semuanya menggunakan tenaga kerja yang berasal dari dalam Desa Pagelaran.

\section{e. Jumlah Biaya}

Tabel 5 memperlihatkan biaya variabel atau biaya modal kerja selama satu musim panen pada perusahaan sampel, biaya modal kerja yang tinggi pada usaha ini merupakan salah satu kendala banyaknya usaha budidaya ikan air tawar tidak konsisten berproduksi. Setiap biaya variabel yang dikeluarkan perusahaan sampel disesuaikan dengan luas kolam produksi dan tebaran benih ikan yang akan di besarkan. Semakin besar volume produksi akan mempengaruhi biaya variabel yang digunakan. Rata-rata biaya variabel yang dikeluarkan oleh responden sebesar Rp. 23.297.637 untuk keperluan produksi selama 3 bulan, mulai dari pengadaan sarana produksi seperti benih dan pakan sampai dengan biaya panen selama 3 bulan. Biaya variabel yang tinggi tidak lepas dari penggunaan pakan, pupuk, dan obat yang berkualitas dan juga biaya perawatan yang relatif tinggi. Hal tersebut dilakukan supaya hasil panen budidaya menghasilkan Ikan air tawar yang berkualitas dan tahan akan penyakit.

Biaya investasi atau biaya modal tetap (Tabel 6) setiap perusahaan sampel berbeda sesuai dengan skala usahanya. Rata- 
Tabel 5 Biaya Variabel (Modal Kerja) Rata-Rata Dari Perusahaan Responden (Rupiah)

\begin{tabular}{|c|c|c|c|c|c|c|}
\hline \multirow{2}{*}{ No } & \multirow{2}{*}{ Uraian } & \multicolumn{4}{|c|}{ Responden } & \multirow{2}{*}{ Rata- Rata } \\
\hline & & $\mathrm{A}$ & $\mathrm{B}$ & $\mathrm{C}$ & $\mathrm{D}$ & \\
\hline 1 & Biaya Sarana Produksi & 20.286 .000 & 12.674 .250 & 3.614 .200 & 2.884 .100 & 9.864 .637 \\
\hline 2 & Biaya Tenaga Kerja & 20.720 .000 & 13.920 .000 & 7.520 .000 & 7.280 .000 & 12.360 .000 \\
\hline 3 & Biaya Sewa & 300 & 300 & 300 & 300 & 300 \\
\hline 4 & Biaya Perawatan Prasarana & 507 & 457 & 407 & 377 & 437 \\
\hline 5 & Biaya Panen & 200 & 200 & 200 & 200 & 200 \\
\hline 6 & Biaya Admnistrasi & 8 & 8 & 8 & 8 & 8 \\
\hline \multirow[t]{2}{*}{7} & Biaya Belanja Prasarana & 128 & 128 & 128 & 128 & 128 \\
\hline & Total & 42.149 .000 & 27.687 .250 & 12.177 .200 & 11.177 .100 & 23.297 .637 \\
\hline
\end{tabular}

Tabel 6 Biaya Modal Tetap Rata-Rata Perusahaan Responden (Dalam Rupiah)

\begin{tabular}{cccc}
\hline No. & Responden & $\begin{array}{c}\text { Biaya } \\
\text { Modal Tetap }\end{array}$ & $\begin{array}{c}\text { Biaya Penyusutan } \\
\text { (3 bulan) }\end{array}$ \\
\hline 1 & A & 206.749 .000 & 3.081 .268 \\
2 & $\mathrm{~B}$ & 134.463 .000 & 2.139 .768 \\
3 & $\mathrm{C}$ & 69.499 .000 & 1.303 .768 \\
4 & $\mathrm{D}$ & 57.629 .000 & 1.172 .934 \\
\hline & Jumlah & 468.340 .000 & 7.697 .738 \\
& Rata-Rata & 117.085 .000 & 1.924 .434 \\
\hline
\end{tabular}

rata responden menghabiskan dana sebesar Rp. 117.085.000 untuk biaya investasi berupa kolam, kendaraan, dan alat-alat yang digunakan untuk proses produksi. Tinggi rendahnya biaya investasi mempengaruhi pengeluaran biaya penyusutan setiap tahunnya. Penyusutan ini dikarenakan setiap barang yang dibeli memiliki nilai unsur pakai sehingga terjadi penyusutan nilai suatu barang yang mengalami penurunan dari tahun ke tahun.

\section{f. Proses Produksi}

\section{- Penyiapan Kolam}

Kolam yang akan digunakan untuk kegiatan produksi ini adalah kolam lumpur, kolam harus dibersihkan terlebih dahulu dengan cara membersihkan lumpur yang masih terdapat pada dasar kolam yang tersisa dari produksi sebelumnya, hal tersebut bertujuan untuk membuang kotoran dari sisa-sisa produksi sebelumnya. Setelah dibersihkan dari lumpur, kemudian diberikan kapur ziolit sebanyak $100 \mathrm{gram} / \mathrm{m}^{2}$. Pengapuran ini bertujuan sebagai salah satu upaya untuk mempertahankan kestabilan tanah sekaligus memberantas hama dan penyakit dalam dalam kolam budidaya ikan. Dosis kapur harus tepat ukurannya karena jika berlebihan akan menyebabkan kolam tidak subur, sedangkan jika kekurangan akan menyebabkan tanah dasar kolam menjadi masam. Selanjutnya dilakukan pemupukkan pada kolam dengan cara menebar pupuk TSP dan Urea ke seluruh dasar kolam dengan dosis masing - masing sebesar $15 \mathrm{gram} / \mathrm{m}^{2}$. Pemupukkan ini bertujuan untuk meningkatkan kesuburan kolam, memperbaiki struktur tanah dan menumbuhkan zooplankton sebagai pakan alami ikan. Setelah itu biarkan kolam produksi terkena sinar mata hari langsung selama kurang lebih 1 hari. Selanjutnya dilakukan pemasangan airasi pada beberapa titik di kolam pemeliharaan setelah itu lakukan pengairan selama 2-3 hari hingga ketinggian air mencapai 1-1,2 $\mathrm{m}$.

- Pendederan benih ke kolam produksi

Setelah pengairan dilakukan, selanjutnya pendederan benih ikan pembesaran ke kolam produksi. Penebaran ini dilakukan pada pagi hari saat suhu air rendah. Sebelum di tebar perlu dilakukan aklimatisasi yaitu menyamakan suhu kantong dengan suhu kolam dengan 
cara memasukkan kantong ke dalam kolam sampai di tandai dengan keluarnya embun di dalam kantong benih. Pada saat penebaran benih dituang secara hatihati dan perlahan ke dalam air agar benih tidak stres.

\section{- Perawatan dan pemberian pakan}

Dalam pembesaran secara intensif, biasanya di utamakan pemberian pakan buatan.pakan yang berkualitas baik mengandung zat-zat makanan yang cukup yaitu protein yang mengandung asam amino esensial, karbohidrat, lemak, vitamin, dan mineral. Selama pemeliharaan, ikan harus diberi makanan tambahan, pakan tambahan yang baik adalah pelet yang mempunyai kandungan protein tidak kurang dari 30 persen dengan dosis pakan yang diberikan adalah 3 5 persen dari berat total benih ikan tebaran. Pemberian pakan dilakukan tiga kali sehari yaitu pada pagi, siang dan sore hari. Pemberian pakan tambahan di lakukan dengan cara menebar langsung ke kolam. Pemberian pakan tidak dilakukan malam hari karena ikan tidak bersifat nokturnal yaitu aktif pada malam hari dan juga suhu pada malam hari cenderung rendah sehingga nafsu makan ikan cenderung rendah pula. Pemberian pakan ini dilakukan selama masa produksi hingga panen biasanya sekitar 90 hari lamanya.

\section{- Pengontrolan}

Kegiatan pengontrolan ini dilakukan selama masa produksi budidaya. Salah satunya yaitu dengan mengontrol pemberian pakan, karena jika berlebihan maka pakan tidak akan termakan sehingga membusuk dan dapat mencemari kolam dan menjadi pemborosan akan pak- an itu sendiri. Selain itu, pengontrolan juga dilakukan pada kolam produksi dan sarana produksi lainnya. Ini biasanya dilakukan oleh tenaga kerja tetap agar mengetahui kondisi ikan maupun kolam produksi. Air yang masuk pada kolam juga harus cukup sesuai dengan rata-rata ketinggian air pada kolam seperti biasanya. Kemudian bila ada tanda-tanda ikan terserang penyakit harus segera diambil tindakan seperti bila ada ikan yang selalu berada di permukaan, gerakannya lamban atau tidak normal dan tidak nafsu makan kemudian jika di tangkap atau di lihat lebih dekat badannya berwarna pucat. Jika terdapat tanda-tanda seperti itu maka ikan harus di pisah untuk diobati.

\section{- Pemanenan}

Pemanenan bisa dilakukan pada pagi hari saat ikan berukuran 3-5 ekor/kg, ukuran ini merupakan ukuran yang banyak diminati konsumen. Untuk mencapai ukuran tersebut umumnya memerlukan masa pemeliharaan sekitar 3 bulan. Proses pemanenan dimulai dengan mempersiapkan alat-alat yang digunakan untuk menangkap ikan seperti seser, jala dan keramba. Selanjutnya mengurangi jumlah air dalam kolam produksi sampai kering dengan membuka pengairan dibantu dengan menggunakan pompa air agar pengeringan air berjalan lebih cepat. Kemudian setelah air surut, lakukan penangkapan secara hatihati agar ikan tidak rusak fisiknya. Setelah itu para tenaga kerja panen akan membagi tugas seperti memindahkan ikan ke dalam keramba buatan dan menimbang berat ikan sebelum mulai proses packing. Packing dilakukan menggunakan kantung plastik ukuran lebar $60 \mathrm{~cm}$ yang telah diisi oleh oksigen di 
dalamnya dan air sebanyak 15 liter dengan $10 \mathrm{~kg}$ ikan per kantung. Hal ini perlu diperhatikan agar ikan tersebut sampai ke konsumen dalam keadaan hidup, segar dan sehat.

\section{- Pembersihan pasca panen}

Setelah selesai panen biarkan kolam produksi terkena sinar matahari langsung. Lalu lepaskan airasi yang terpasang pada kolam pembesaran dan bersihkan, kemudian setelah itu seperti persiapan kolam produksi diawal, mulai dari membersihkan lumpur yang ada dalam kolam sampai melakukan pemupukkan dan pengapuran pada kolam agar kolam steril dari hama dan tanahnya tetap subur.

\section{- Manajemen}

Kendala aspek manajemen yang dihadapi oleh setiap pembudidaya ikan air tawar di Desa Pagelaran ini adalah administrasi yang masih kurang diperhatikan, sehingga setiap pengeluaran biaya maupun pemasukan tidak semua tercatat di administrasi perusahaan. Hal tersebut menjadi salah satu penghambat perkembangan usaha ini karena sulitnya menentukan persiapan ataupun peramalan di musim produksi yang akan datang. Rata-rata perusahaan sampel hanya melakukan pencatatan pengeluaran pakan, benih dan pupuk sedangkan pengeluaran lain tidak dilakukan pencatatan.

\section{Analisis Kelayakan Tak Berdiskonto}

Berdasarkan perhitungan didapat hasil nilai Benefit Cost Ratio senilai 1,73. Artinya setiap Rp.1 biaya yang dikeluarkan menghasilkan manfaat bersih sebesar Rp. 1,73. Nilai B/C Ratio lebih dari 1 artinya usaha ini layak untuk dikembangkan.
BEP merupakan titik impas terjadinya keseimbangan antara total penerimaan dan total biaya, artinya total penerimaan sama dengan total biaya yang dikeluarkan. Analisa BEP dapat digunakan untuk merencanakan segala sesuatu karena dapat dihitung berapa produksi ( $\mathrm{kg}$ ) maupun penerimaan (Rp.) yang harus dicapai agar memperoleh keuntungan dan dapat menghitung berapa harga jual ( $\mathrm{Rp} / \mathrm{kg})$ agar mendapat keuntungan dari total biaya produksi yang dikeluarkan petani (Suratiyah, 2008). BEP produk dalam usaha budidaya ikan terjadi ketika total biaya sama dengan harga rata-rata ikan dipasar. Berdasarkan perhitungan BEP dari segi kuantitas senilai $1.073 \mathrm{Kg}$. Artinya pembudidaya harus menjual sebanyak 1.073 $\mathrm{kg}$ untuk mengembalikan modal usahanya. Semakin rendah jumlah unit maka semakin cepat titik pulang pokok suatu usaha. Sedangkan untuk BEP dari segi nilai harga berada pada saat penjualan menghasilkan harga sebesar Rp. 13.502.

Berdasarkan perhitungan diperoleh nilai ROI sebesar 73,3\%. Hal ini menunjukan persentase pengembalian keuntungan yang didapat dibandingkan dengan jumlah investasi modal sebesar 73,3 $\%$. Semakin besar nilai ROI maka semakin besar keuntungan yang didapat.

\section{Analisis Kelayakan Berdiskonto}

Berdasarkan perhitungan diperoleh nilai NPV sebesar Rp. 107.754.412 (Tabel 7). Hal ini mengartikan bahwa usaha budidaya ikan air tawar komoditi mas di Desa Pagelaran Kecamatan Pagelaran Kabupaten Pringsewu menghasilkan Rp. 107.754.412 selama 2,5 tahun dengan discount rate yang digunakan sebesar $8 \%$. Nilai NPV lebih dari 1 
artinya usaha ini layak untuk dikembangkan.

Berdasarkan perhitungan diperoleh nilai Net B/C senilai 1,92 (Tabel 7). Hal ini menunjukan bahwa setiap Rp.1 biaya dikeluarkan untuk usaha ini akan menghasilkan manfaat sebesar Rp. 1,92. Hasil ini menyatakan bahwa usaha budidaya ikan air tawar ini layak untuk dikembangkan.

Berdasarkan perhitungan diperoleh Gross B/C sebesar 1,34 (Tabel 7). Hal ini menggambarkan ratio antara benefit kotor dan cost secara keseluruhan yang telah di discount. Nilai Gross B/C > 1 artinya usaha layak untuk dikembangkan.

Berdasarkan perhitungan diperoleh nilai IRR sebesar 21,86\% (Tabel 7), artinya hasil dari usaha budidaya ikan air tawar tersebut mampu mengembalikan $21,86 \%$ dari modal yang dikeluarkan. Dengan tingkat IRR tersebut usaha budidaya ikan air tawar ini dikatakan layak untuk dikembangkan karena nilai IRR lebih besar dibandingkan tingkat discount factor $8 \%$.

Berdasarkan hasil perhitungan Payback Periode, diperoleh bahwa waktu yang diperlukan untuk pengembalian investasi yaitu 12 bulan 63 hari atau 1 tahun 2 bulan 3 hari (Tabel 7). Nilai payback periode tidak lebih dari umur usaha yaitu 2,5 tahun sehingga usaha ini layak untuk dikembangkan.

Menurut Yuwani et al. (2014) bahwa suatu usaha budidaya ikan air tawar dinilai layak untuk dikembangkan jika nilai NPV positif lebih besar dari 0 dan nilai net $\mathrm{B} / \mathrm{C}$ ratio lebih besar dari $1 \mathrm{da}-$ pat meskipun terjadi penurunan penerimaan sebesar $10 \%$ jika kenaikan biaya produksi dan penurunan penerimaan terjadi secara bersamaan sebesar $10 \%$.
Analsisis sensitivitas bertujuan untuk melihat apa yang akan terjadi dengan proyek jika suatu kesalahan atau perubahan dalam dasar-dasar perhitungan biaya atau benefit. Analisis sensitivitas pada usaha budidaya ikan dilakukan untuk melihat seberapa besar usaha perbenihan mampu bertahan bila faktor produksi ataupun pnerimaan mengalami kenaikan maupun penurunan ( $\mathrm{Yu}$ wani et al., 2014).

Pada Tabel 8 menunjukan hasil analisis sensitivitas dengan metode switching value pada saat terjadi penurunan tingkat produksi. Pada saat penurunan tingkat produksi $10 \%$ usaha tetap layak dikembangkan karena nilai NPV $>0$ dan nilai Net $\mathrm{B} / \mathrm{C}>1$. Batas penurunan tingkat produksi maksimum terjadi pada saat penurunan produksi mencapai $25 \%$. Pada saat tersebut nilai NPV mendekati 0 yaitu Rp. 1.851 .345 yang artinya usaha tersebut mendekati titik pulang pokok dan nilai Net $\mathrm{B} / \mathrm{C}=1$ artinya nilai kas keluar sama dengan nilai kas masuk. Pada saat penurunan produksi menyentuh angka $26 \%$ usaha tidak lagi layak untuk dikembangkan karena nilai NPV $<0$ dan nilai Net $\mathrm{B} / \mathrm{C}<1$ artinya usaha rugi.

Tabel 9 menunjukan hasil analisis sensitivitas dengan metode switching value pada saat terjadi peningkatan biaya produksi. Pada saat peningkatan biaya produksi sebesar $10 \%$ usaha tetap layak dikembangkan karena nilai NPV > 0 dan nilai Net $\mathrm{B} / \mathrm{C}>1$. Batas peningkatan biaya maksimum terjadi pada saat peningkatan biaya produksi mencapai $54 \%$. Pada saat tersebut nilai NPV mendekati 0 yaitu Rp. 408.955 yang artinya usaha tersebut mendekati titik pulang pokok dan nilai Net $\mathrm{B} / \mathrm{C}=1$ artinya nilai kas keluar sama dengan ni- 
Tabel 7 Hasil Perhitungan analisis berdiskonto

\begin{tabular}{ccccc}
\hline No. & Alat Analisis & Kriteria Investasi & Nilai & Keterangan \\
\hline 1 & NPV & Lebih dari 0 & Rp.107.754.412 & Layak \\
2 & Net B/C & Lebih dari 1 & 1,92 & Layak \\
3 & Gross B/C & Lebih dari 1 & 1,34 & Layak \\
4 & IRR & Lebih dari suku bunga (r) & $21,86 \%$ & Layak \\
5 & Payback Periode & Kurang dari 2,5 tahun & 1 tahun 2,3 bulan & Layak \\
\hline
\end{tabular}

Tabel 8 Analisis sensitivitas penurunan tingkat produksi

\begin{tabular}{llcccc}
\hline \multirow{2}{*}{ No. } & \multirow{2}{*}{ Parameter } & Persentase & NPV & Net & \multirow{2}{*}{ Keterangan } \\
\cline { 3 - 5 } & & Penurunan & (Rupiah) & B/C & Layak \\
\hline 1 & Penurunan Produksi & $10 \%$ & 65.393 .203 & 1,55 & Pulang Pokok \\
2 & Penurunan Produksi & $25 \%$ & 1.851 .345 & 1 & Tidak Layak \\
3 & Penurunan Produksi & $26 \%$ & -2.384 .779 & 0,97 & T. \\
\hline
\end{tabular}

Tabel 9 Analisis Sensitivitas Peningkatan Biaya Produksi

\begin{tabular}{lccccc}
\hline \multirow{2}{*}{ No. } & \multirow{2}{*}{ Parameter } & Persentase & NPV & Net & \multirow{2}{*}{ Keterangan } \\
\cline { 3 - 5 } & & Peningkatan & (Rupiah) & B/C & Layak \\
\hline 1 & Peningkatan Biaya & $10 \%$ & 87.875 .646 & 1.7 & Pulang Pokok \\
2 & Peningkatan Biaya & $54 \%$ & 408.955 & 1 & Tidak Layak \\
3 & Peningkatan Biaya & $55 \%$ & -1.578 .926 & 0,98 & . \\
\hline
\end{tabular}

lai kas masuk. Pada saat peningkatan biaya produksi menyentuh angka 55\% tidak lagi layak untuk dikembangkan karena nilai NPV $<0$ dan nilai $\mathrm{Net} \mathrm{B} / \mathrm{C}$ $<1$ artinya usaha rugi.

Pada aspek produksi, pemilik budidaya harus lebih efisien lagi dalam penggunaan input sarana produksi seperti pakan, obat dan pupuk sehingga biaya produksi bisa diminimalisir lagi guna mencapai keuntungan yang maksimal dari usaha budidaya ikan air tawar komoditi ikan mas di Desa Pagelaran Kecamatan Pagelaran Kabupaten Pringsewu. Selain itu juga pembudidaya harus berani mengembangkan usahanya supaya dapat memenuhi permintaan pasar terhadap ikan mas. Pada aspek manajemen, para pemilik budidaya kedepannya harus memperhatikan admi- Simpulan penelitian ini bahwa usaha nistrasi perusahaan. Seperti melakukan pembukuan yang lebih baik lagi, sehingga arus kas masuk dan keluar dapat tercatat dengan baik. Hal tersebut dapat dijadikan pedoman untuk melihat prospek usaha kedepannya, serta di- jadikan dasar dalam mengambil keputusan untuk pengembangan usaha tersebut. Bagi pemerintah setempat untuk lebih melakukan pengawasan terhadap usaha ini karena usaha ini menjadi salah satu penyumbang pendapatan daerah yang cukup tinggi kepada Kabupaten Pringsewu. Pemerintah dapat melakukan pelatihan pembukuan kas ke pembudidaya dan juga memberikan fasilitas yang berkaitan dengan usaha ini seperti adanya pasar induk khusus atau koperasi yang menyediakan bahan baku produksi agar lebih memudahkan para pembudidaya untuk mengembangkan usahanya.

\section{SIMPULAN} budidaya ikan air tawar di Kabupaten Pringsewu layak untuk dikembangkan berdasarkan pertimbangan bahwa aspek non finansial (aspek pemasaran, aspek produksi dan aspek manajemen) usaha budidaya ikan air tawar memiliki po- 
tensi untuk dikembangkan dan aspek finansial (analisis kelayakan tanpa diskonto dan analisis kelayakan berdiskonto) usaha budidaya ikan air tawar menguntungkan dan layak untuk dikembangkan sehingga dapat meningkatkan pendapatan petani.

\section{Pustaka}

Bambang, R. (2001). Dasar-dasar pembelanjaan perusahaan. Edisi Keempat, Cetakan Ketujuh, BPFE Yogyakarta, Yogyakarta, 59.

Gaspersz, V. (2002). Pedoman implementasi program six sigma terintegrasi dengan iso 9001: 2000, mbnqa, dan haccp. PT. Gramedia Pustaka Utama, Jakarta.

Hanafi, M. M. (2010). Manajemen keuangan: Teori dan aplikasi. Yogyakarta: BPFE $U G M$.

Harjito, A. and Martono, S. (2005). Manajemen keuangan. Edisi Pertama. Yogyakarta: Ekonisia.

Ibrahim, H. Y. (2003). Studi kelayakan bisnis. PT Rineka Cipta.

Lampung, B. P. S. (2019). Provinsi lampung dalam angka 2019.

Pringsewu, D. P. K. (2017). Jumlah produksi budidaya ikan air tawar di kabupaten pringsewu tahun 2017.

Statistik, B. P. (2019). Statistik indonesia 2019.

Sudana, S., Arga, I., and Suparta, N. (2013). Kelayakan usaha budidaya ikan lele dumbo (clarias gariepinus) dan pengaruhnya terhadap tingkat pendapatan petani ikan lele di kabupaten tabanan. JURNAL MANAJEMEN AGRIBISNIS (Journal Of Agribusiness Management).

Sugiyono, D. (2008). Metode penelitian bisnis. Bandung: Pusat Bahasa Depdiknas.

Syamsuddin, L. (2007). Manajemen keuangan perusahaan: Konsep aplikasi dalam perencanaan, pengawasan, dan pengambilan keputusan. Jakarta: PT Raja Grafindo Persada.

Yuwani, S. H., Irham, I., and Jamhari, J. (2014). Analisis kelayakan dan strategi pengembangan usaha budidaya ikan air ta- war di kabupaten sleman. Agro Ekonomi, 25(2):135-143.

Kontribusi: Sirat, M: mendesain penelitian, merancang metode pengambilan sampel, menyiapkan dan editing manuskrip; Shaleh, S: analisis data; Ermawaty, R; Sirat, M.M.P; Utomo, D.S.C: pengambilan data, pengumpulan data sekunder, persiapan manuskrip. 
